\title{
LA IGLESIA EN LA FORMACIÓN NACIONAL HISPANOAMERICANA Y EN LOS ORÍGENES DE SU ESTADO CONSTITUCIONAL
}

\author{
POR \\ MARÍA NÚÑEZ MARTÍNEZ \\ Profesora colaboradora doctora. \\ Departamento de Derecho Político. UNED.
}

\section{ANTECEDENTES: LA IGLESIA EN LA CONFORMACIÓN DEL IMPERIO ESPAÑOL}

No es posible encontrar en el origen de Estado Moderno alguno una unión tan grande entre la religión y la Corona como en el nacimiento y conformación de la Monarquía renacentista española. A este respecto, la explicación es obvia, el poder político, en el proceso de creación de las Monarquías Autoritarias, tratando de imponerse a los diversos poderes locales, precisaban de elementos aglutinantes que coadyuvaran a la conformación de un sentimiento nacional. En este sentido, cuando se produce el acceso al trono de los Reyes Católicos en Castilla y Aragón, en su deseo de crear una unidad nacional española en las postrimerías del siglo XV, no se cuenta con el aglutinante lingüístico, como en la Francia contemporánea, ya que España no contaba con un idioma único, pues cada Reino tenía una lengua diferente, así como varios dialectos, y de hecho, hasta principios del siglo XVIII, con la llegada del centralismo borbónico no se impuso el castellano como lengua oficial del Estado. Tampoco podían establecerse razones de carácter étnico, como fue el caso de Alemania en el momento de conformar su unidad nacional mediante el concepto del pangermanismo, pues no 
existía raza predominante alguna, aunque sí un considerable mestizaje. Respecto a una cultura y creencias comunes, tampoco era muy perceptible, en virtud fundamentalmente de la división entre la España cristiana y la musulmana imperante durante ocho siglos, existía quizás en este aspecto un cierto recuerdo de pasado común remontándose a la España visigótica de mil años atrás, que por otra parte no abarcaba tampoco a la totalidad del territorio peninsular. Aunque la religión cristiana no era tampoco única en el territorio, sí era el elemento aglutinante de la mayoría de la población, en cuanto que los que no la profesaban eran o una minoría, que presentaba aspectos marginales, caso de la hebraica, o los habitantes de un reino vencido, caso de los granadinos.

Es pues, en este contexto en el que el poder político se apoyará en la religión como elemento unificador, de donde se deriva la importancia que la religión jugará posteriormente en el Estado ${ }^{1}$.

Por otra parte, la utilización de la religión como elemento aglutinante del elemento nación, tiene una implicación diferente y mucho más enraizada en la historia no sólo de la península ibérica sino en todo el continente europeo, que el aglutinante lingüístico o racial, ya que durante el largo periodo de la Edad Media, el único sentido unitario existente es el de profesar una determinada religión; así, lo que caracteriza a los habitantes de los diversos reinos es el ser cristianos como contraposición del hecho musulmán. Por otra parte, cabe destacar que la única entidad claramente organizada es la Iglesia, que continúa dentro de los moldes establecidos durante el Imperio Romano, de tal forma, que puede superponer su poder al poder temporal y sustituir la vieja concepción de civitas romana por la de civitas cristiana como único elemento aglutinante.

De esta forma, la instrumentalización de la religión como elemento representativo de la unidad nacional, supone, a diferencia de los otros indicados anteriormente, que la unidad tendrá su base no en el libre juego de una población, que evolucionará en un sentido determinado, procediendo a las transformaciones que hubiere lugar, como es el caso de la lengua, sino que deberá contar con una institución, la Iglesia Católica, que es incluso anterior al Estado y que es depositaria del desarrollo que se produzca en este elemento aglutinante del Estado, de manera, que cualquier cambio o evolución será consecuencia no del protagonismo de la nación, sino de la institución, que encarna el poder espiritual, que de esta forma se convierte en la única institución existente en el Estado que no está sujeta al poder del mismo y que a su vez tiene una influencia decisiva en el desarrollo del propio Estado.

${ }^{1}$ Núñez Rivero, C. Derecho Constitucional Comparado y Derecho Político iberoamericano, Ed. Universitas, Madrid UNED, 2002, págs. 30 y ss. 
La transformación de la Monarquía española en Imperio acentuó más si cabe la importancia de la religión como aglutinante del Estado, ya que el acceso del Rey Carlos I a la Corona imperial con el título de Carlos V suponía la herencia del viejo Imperio Sacro Romano Germánico, que tenía su justificación en la representación del poder temporal de Dios como Vicario en la tierra, teoría que sería especialmente defendida por los teólogos españoles de la época. El concepto de Monarquía Múltiple que se desarrollará durante el reinado de Carlos I, Felipe II y los restantes Habsburgos implicará la unión no sólo por la figura del Monarca, sino por la religión compartida, aspecto que se incrementará, una vez que se desgajen de esta forma de Monarquía Universal los territorios centroeuropeos que pasarán tras la abdicación de Carlos $\mathrm{V}$ a la rama de los Habsburgo austriacos y que es donde precisamente se habían producido los brotes del movimiento protestante. De esta forma, la totalidad de los territorios sujetos al concepto de imperio español, con la excepción de los Países Bajos, donde se producirán interminables guerras de religión, que en el fondo disfrazarán luchas por la independencia y por la incipiente revolución burguesa holandesa, estarán sujetos a la Religión Católica, y será objetivo primordial del trono su defensa, sea en el Mediterráneo contra la expansión turca, como en el continente europeo e Inglaterra contra la «herejía» protestante, pero siempre en defensa del Papado.

\section{LA IGLESIA EN LA FORMACIÓN ESTATAL AMERICANA}

En este contexto descrito en el epígrafe anterior se inicia la conquista y colonización de las nuevas tierras americanas. Cabe destacar que desde las primeras expediciones de descubrimiento y asentamiento en los nuevos territorios se pone de manifiesto el interés por parte de la Corona de llevar a los nativos de aquellas tierras el conocimiento de la Religión Católica:

«que sus ánimas no se pierdan, para lo cual es menester que sean informados de las cosas de nuestra santa fe católica ${ }^{2}$.

Las razones de la Corona para la expansión de la religión a las Indias, es consecuencia en principio, de la doctrina de la teocracia ${ }^{3}$, desarrollada en el Medioevo a favor de la universal soberanía papal, que legitimaba la adquisición de nuevos territorios para los monarcas cristianos, en virtud de que ello significara la incorporación al seno de la Iglesia de estos pueblos, de tal forma, que «el descubrimiento y ocupación por un príncipe cristiano de tierras habitadas por in-

2 Real cédula de 1509.

3 Castañeda, P. La Teocracia pontifical y la conquista de América Vitoria, 1968. 
fieles con ánimo de convertirlos a la fe católica constituía un título legítimo suficiente de adquisición de las mismas, según el derecho de la época ${ }^{4}$, de tal forma, que sobre los Príncipes cristianos convertidos en soberanos pesaba el deber de misionar y de establecer allí el conjunto de ordenaciones precisas para hacer posible la vida religiosa de un pueblo cristiano 5 , así mismo, podemos entender que tal actitud de la Corona se deriva del propio sentimiento religioso de los monarcas, así como del interés de conformar una sociedad en aquellas tierras similar a la existente en la península, regida por las mismas normas y costumbres; a tal efecto, podemos indicar los controles impuestos para la emigración de la población europea al Nuevo Mundo, controlada por la Casa de la Contratación $^{6}$, a la que se sumaría pronto la Inquisición ${ }^{7}$ que a principios del siglo XVI comenzaría sus actividades en las Indias ${ }^{8}$. Estos controles impedían la emigración a las Indias de toda persona que no profesara la Religión Católica Apostólica Romana, impidiendo incluso el acceso de conversos castellanos.

La evangelización americana se produce mediante la tutela del Estado y no teniendo como centro de impulsión el Vaticano, poniéndose de manifiesto la incardinación de la acción religiosa en el contexto de la política imperial. A este efecto, el Papado debió conceder una serie de privilegios, conocidos como el derecho de patronato americano'; cuya ley citamos, en virtud de su importancia,

${ }^{4}$ García Gallo, A., Las Bulas alejandrinas. Madrid, 1987, págs. 661-662.

5 Véase De la Hera, A., Soler, C.; «Historia de las doctrinas sobre las relaciones entre la Iglesia y el Estado», en VVAA. Tratado de Derecho Eclesiástico. Pamplona, 1994, págs. 35-84.

${ }^{6}$ La Casa de la Contratación se conformó mediante Real Cédula de 1503, teniendo como objetivo fundamental en su origen el control de comercio con las Indias, en lo referente a importación y exportación, posteriormente, en virtud del auge de dicho comercio y de la emigración a las Indias se incrementarían sus atribuciones, incorporando algunas de carácter judicial «ley 16, Título I, Libro 9 de la Recopilación de Indias», "Real Provisión de 26 de septiembre de 1511".

7 Los primeros Comisarios del Santo Oficio en tierras americanas fueron el Obispo Manso en Puerto Rico y el dominico Pedro de Córdoba en la isla Española.; posteriormente se trasplantaría a Nueva España (1535) y Perú (1539); no obstante, desde 1517 todos los Obispos de las Indias tenían poderes inquisitoriales.

${ }^{8}$ La cédula fundacional del Tribunal de la Inquisición data de 1569; el primer Tribunal se estableció en Lima en 1570, posteriormente lo hizo el de México en 1571, siendo el tercero el de Cartagena de Indias en 1610.

9 Entre otros podemos citar las bulas papales «Eximia devotionis» de 3 de mayo de 1493, que concedía a los Reyes Católicos en las Indias las mismas prerrogativas de que gozaban los monarcas portugueses en sus territorios africanos, la "Universalis Ecclesiae», de 28 de julio de 1508,durante el pontificado de Julio II, que establecía que a cambio de que los Reyes pudieran presentar a las autoridades eclesiásticas en las Indias, corrieran con las cargas económicas inherentes al proceso de implantación de la Iglesia Católica en América, la "Exponi nobis», de 9 de junio de 1522, que otorgaba a la Corona el derecho a decidir el número de religiosos que podían estable- 
«Por cuanto el derecho de el Patronazgo Eclesiástico nos pertenece en todo el Estado de las Indias, así por haberse descubierto y adquirido aquel Nuevo Mundo, edificado y dotado en él las Iglesias y Monasterios á nuestra costa, y de los Señores Reyes Católicos nuestros antecesores, como por habérsenos concedido por Bulas de los Sumos Pontífices de su propio motu, para su conservación y de la justicia que á él tenemos: Ordenamos y mandamos, que este derecho de $\mathrm{Pa}$ tronazgo de las Indias único é in solidum siempre sea reservado á Nos y á nuestra Real Corona, y no pueda salir de ella en todo, ni en parte, y por gracia, merced, privilegio, ó cualquier otra disposición que Nos, ó los Reyes nuestros Sucesores hiciéramos, ó concediéramos no sea visto que concedemos derecho de Patronazgo á persona alguna, Iglesia, ni Monasterio, ni perjudicarnos en el dicho nuestro derecho de Patronazgo. Otrosí por costumbre, prescripción, ni otro título ninguna persona, Comunidad Eclesiástica, ni Seglar, Iglesia, ni Monasterio puedan usar de derecho de Patronazgo, si no fuere la persona que en nuestro nombre, y con nuestra autoridad y poder lo ejerciere; y que ninguna persona Secular, ni Eclesiástica, Orden, ni Convento, Religión, ó Comunidad, de cualquier estado, condición, calidad y preeminencia, judicial ó extrajudicialmente, por cualquier ocasión ó causa, sea osado á entrometerse en cosa tocante al dicho Patronazgo Real, ni á Nos perjudicar en él, ni á proveer Iglesia, ni Beneficio, ni Oficio Eclesiástico, ni á recibirlo, siendo proveído en todo el Estado de Indias, sin nuestras presentación, ó de la persona á quien Nos por Ley, ó provisión patente lo cometiéramos; y el que lo contrario hiciere, siendo persona Secular, incurra en perdimiento de las mercedes que de Nos tuviere en todo el Estado de las Indias, y sea inhábil para tener y obtener otras, y desterrado perpetuamente de todos nuestros Reynos; y siendo Eclesiástico sea habido y tenido por extraño de ellos, y no pueda tener ni obtener Beneficio, ni oficio Eclesiástico en los dichos nuestros Reynos, y unos y otros incurran en las demás penas establecidas por leyes de estos Reynos; y nuestros Virreyes, Audiencias y Justicias Reales procedan con todo rigor contra los que faltaren á la observancia y firmeza de nuestro derecho de $\mathrm{Pa}$ tronazgo, procediendo de oficio, ó á pedimento de nuestros Fiscales, ó de cualquiera parte que lo pida, y en la execución de ello pongan la diligencia necesaria» ${ }^{10}$.

De esta forma, se establece en los territorios americanos una organización de carácter similar a la existente en Castilla ${ }^{11}$, aunque con mayor protagonismo es-

cerse en los nuevos territorios, así como a vetar a aquellos que deseara, sin que debiera consultar a las autoridades religiosas en el territorio metropolitano su más directo precedente es la bula de Inocencio VIII de 1486, para el establecimiento de Patronato de Granada.

${ }_{10}$ "Que el Patronazgo da las indias pertenece privativamente al Rey, y á su Real Corona, y no pueda salir de ella en todo, ni en parte» Ley 1, título VI, Libro I, Recopilación de Indias.

${ }^{11}$ Se produce como consecuencia del avance de la denominada «Reconquista» en España y la incorporación de territorios musulmanes a los Reinos cristianos. Como antecedentes próximos 
tatal $^{12}$, así, para el nombramiento de obispos y arzobispos en tierras americanas, era preciso que el Consejo de Indias, confeccionara una terna para cada caso, y la presentara al Monarca, que a su vez, elegido el candidato, proponía al Papa, quien procedía a su nombramiento ${ }^{13}$. Aunque, no obstante, no podía tomar posesión del mismo, hasta jurar solemnemente ante escribano público,

«no contravenir en tiempo alguno, ni por ninguna manera á nuestro Patronazgo Real, y que lo guardarán y cumplirán en todo y por todo, ni estorbarán el uso de nuestra Real jurisdicción, y la cobranza de nuestros derechos y rentas reales, que en cualquier manera nos pertenezcan, ni la de los dos novenos, que nos están reservados en los diezmos de las Iglesias de las Indias» ${ }^{14}$.

Así mismo, no podía abandonar su sede sin permiso del Rey ${ }^{15}$,

«(...) Mandamos a los Virreyes, Presidentes y Oidores, que no dén á los Arzobispos, ú Obispos licencia para venir á estos Reynos, y á los Gobernadores y Alcaldes mayores y otros nuestros jueces, que no los consientan ni dexen venir, si no fuere teniendo expresa licencia nuestra para venir, ni los dexen embarcar en ninguna manera, ni por ninguna vía, porque así conviene al servicio de Dios nuestro Señor, y al nuestro, y bien de los naturales y Españoles, que residen en aquellas provincias» ${ }^{16}$,

y en el caso de los clérigos o religiosos sin el permiso de sus Prelados, el cuál estaba condicionado, en el caso de que fueran predicadores,

«(...) los Prelados no les darán licencia, si no les constare que han residido diez años, por lo menos, en aquellas Provincias para el dicho ministerio» ${ }^{17}$, debiendo

cabe destacar la Bula Orthodoxae fidei, otorgada el 13 de diciembre por Inocencio VIII, mediante la cuál se daba los Reyes Católicos el patronato universal sobre todas las Iglesias del Reino de Granada, así como de las Islas Canarias.

12 Se suelen diferenciar tres etapas en el desarrollo de las atribuciones de la Corona respecto a las cuestiones religiosas: a) El Patronato, correspondiente al inicio, b) El Vicariato que comienza a finales del siglo XVI y se desarrolla en el siglo XVII, c) Las Regalías correspondientes al reinado de la Casa de Borbón.

13 «Que los Arzobispados, Obispados y Abadías sean proveidos por presentación del Rey á su Santidad» Ley 3 y ss, Título VI, Libro 1, Recopilación de Indias.

${ }^{14}$ Ley 1, Título VII, Libro I, Recopilación de Indias.

15 Ley 36, Libro VII, Libro II, Recopilación de indias.

16 Posteriormente, mediante la Ley 18, Título XII, Libro I, Felipe II, se proclamaba «Mandamos á nuestros Virreyes, que tengan particular cuidado de no dar licencias á clérigos para venir á estos Reynos á sus pretensiones, aunque las tengan de sus Prelados».

17 Ley 16, Título XII, Libro II, Recopilación de indias. 
contar asimismo con la licencia del Virrey o Gobernador en cuyo distrito hubieren estado.

El control por parte del Estado de la actividad religiosa en América se consolida mediante el «Pase Regio», obtenido por el emperador Carlos V en 1538, mediante el cual los documentos remitidos por el papado a la Iglesia americana, precisaban de la autorización real; así como la obligación por parte de los Obispos americanos de enviar a la Corona cualquier petición que desearan hacer al $\mathrm{Papa}^{18}$.

Valga como ejemplo de superposición de la autoridad real sobre el Vaticano, el no cumplimiento y ejecución de las Bulas y Breves apostólicos dados por el Sumo Pontífice, en el caso de que se considerase fueran en contra del Real Patronazgo ${ }^{19}$,

«(...) — se cumplan — si no fuese en derogación, ó perjuicio de nuestro Real Patronazgo, Privilegios y Concesiones Apostólicas, que los Señores Reyes nuestros Progenitores, y Nos tenemos de la Santa Sede, y nos pertenecen por derecho y costumbre, y suspendan la execución de las Letras, Bulas y Breves, que en contavención de esto y nuestra Real preeminencia y Patronazgo se despacharen, y nos den cuenta de ello, para que interponiendo los remedios legítimos y necesarios, supliquemos á Su Santidad, que mejor informado, no dé lugar, ni permita se haga perjuicio, ni novedad en lo que á Nos y á nuestros Progenitores ha pertenecido y pertenece por derecho, gracias Apostólicas y costumbre, porque así conviene para el servicio de Dios nuestro Señor, gobierno Eclesiástico by temporal y quietud de las Indias, y que esto mismo se cumpla, guarde y execute en cualesquiera Letras y Patentes que dieren los Prelados de las Religiones, según y como hasta ahora se observa y guarda»,

siendo por otra parte obligatorio que las Bulas y Breves que se emitieran para las Indias, debían ser presentadas en el Consejo de Indias y contar con su aprobación,

«(...) Mandamos á los Virreyes, Presidentes y Oidores de las Reales Audiencias, que los recojan todos originalmente de poder de cualesquier personas que los tuvieren, y habiendo suplicado de ellos para ante Su Santidad, que esta calidad ha

${ }^{18}$ Como indica Maqueda, C. «Evolución del Patronato Regio. Vicariato Indiano y conflictos de competencias». En El Gobierno de un mundo. Virreinatos y Audiencias en la América Hispánica, Cuenca, Univ. Castilla La Mancha, 2004, págs. 539-600, pág. 828. El Pase Regio fue una fuente clara de conflictos y enfrentamientos entre los dos poderes, «(...) estamos ante otro exceso de la jurisdicción real que es de difícil justificación».

${ }^{19}$ Ley 1, Título IX, Libro I de la Recopilación de Indias. 
de preceder, nos las envíen en la primera ocasión al dicho nuestro Consejo; y si vistos en él fueren tales, que se deban ejecutar, sean ejecutados; y teniendo inconveniente, que obligue á suspender su execución, se suplique de ellos para ante nuestro muy Santo Padre, que siendo mejor informado, los mande revocar, y entre tanto provea el Consejo que no se ejecuten, ni se use de ellos» ${ }^{20}$.

Por el contrario, no consiguió la Corona el nombramiento de un Vicariato específico para la Iglesia americana, aunque sí un Patriarcado de Indias, con sede en Sevilla, con carácter más honorífico que efectivo ${ }^{21}$; sin embargo, tampoco el Papa pudo nombrar un Nuncio para las Indias, lo que hubiera supuesto un control más efectivo de Roma sobre las actividades de la Iglesia en el Nuevo Continente.

No se escapaba al control estatal la actividad de las órdenes religiosas, que tanta influencia tuvieron en la evangelización del Nuevo Mundo ${ }^{22}$, así, aunque la jerarquía de las órdenes religiosas culminaba en un ministro general (franciscanos) o un maestro general (dominicos), que tenían su sede en Roma, que no estaban sujetos al denominado "derecho de presentación», su actividad en las tierras americanas estaba supeditada en ocasiones a un vicario general de la congregación que vivía en España, caso de los franciscanos, y en todo caso, la Corona gozaba de derecho de autorizar el acceso de sus miembros a los territorios americanos, previa petición de la jerarquía de las órdenes respectivas, que se tramitaba por los funcionarios reales de las Indias que las transmitían al Consejo de Indias.

Por otra parte, aunque las órdenes elegían a sus maestros provinciales en las Indias, que ejercían su mandato por un periodo limitado a un máximo de seis años, sin que interviniera la Corona, en virtud de que no eran propuestos a

${ }^{20}$ Ley 2, Título IX, Libro I de la Recopilación de Indias.

${ }^{21}$ La creación de Archidiócesis en Santo Domingo, México, Lima y Santa Fe de Bogotá, significaron un mayor control de la actividad religiosa por la Corona, constituyendo una alternativa al vicariato solicitado.

22 Como indica Lucena Salmoral, M.: «La actividad del clero regular en América fue enorme, hasta el punto de que puede decirse que la Iglesia indiana del siglo XVI fue de frailes. Los franciscanos y mercedarios llegaron en 1493, los dominicos en 1510, los agustinos en 1532 y los jesuitas en 1566. Entre 1493 y 1600 pasaron al Nuevo Mundo 5.428 religiosos regulares, que controlaron las misiones, las parroquias (particularmente al fundarse ciudades) y hasta los altos cargos de la administración eclesiástica. Baste decir que de los 214 obispos nombrados en dicha centuria 142 fueron regulares. Durante el siglo XVII disminuiría la importancia del clero regular en América, pero continuó siendo fundamental. Baste decir que en 1650 tenía 12.000 religiosas sólo en la América española, y la mayor parte de ellos criollos o mestizos». Estructura uniforme de Iberoamérica como Región. En Historia de Iberoamérica, Tomo II, Ed. Cátedra, 1990, pág. 408. 
través del Regio Patronato, su independencia estaba limitada, pues como indica Manuel Lucena Salmoral ${ }^{23}$ "lo que en realidad permitió el control de la iglesia regular americana fue la implantación del Decreto del Concilio de Trento de que ningún clérigo ejerciese jurisdicción sobre seglares, ni cura de almas, si no dependía directamente de un obispo. Dicho Decreto entró en vigor en 1574 y significó que todo el clero regular que ejercía sacerdocio sobre la población española (peninsular, criolla y mestiza) dependería en el futuro de una autoridad nombrada por el Regio Patronato. La decisión fue tomada para evitar abusos y pensando en Europa, pero tuvo enorme repercusión en América, ya que las antiguas iglesias levantadas por los misioneros regulares, que se habían convertido a lo largo de los años en parroquias de seglares, donde continuaban ejerciendo los regulares, debían ahora ser entregadas al clero secular nombrado por el $\mathrm{Pa}-$ tronato Regio, que además era minoritario... (...) el asunto tenía toda clase de consideraciones. Quizá la más evidente era la económica, ya que las parroquias eran rentables y las misiones no. Con estas medidas se conseguía además que los regulares acabaran sometidos por el Regio Patronato, o bien quedaran relegados a constituir únicamente una fuerza de choque en las zonas fronterizas de la conquista y colonización. Como contrapartida, el Consejo de Indias incorporó a numerosos regulares a la jerarquía eclesiástica indiana, procurando establecer en ésta un cincuenta por ciento para cada uno de los dos sectores: regulares y seculares $^{24}$.

La entronización de la Casa de Borbón en España supuso un intento más de control por parte del Estado de las actividades eclesiásticas en el continente americano, así junto a las reformas administrativa que se llevaron a cabo durante el siglo XVIII, tendentes a la centralización del Estado, entre las que debemos destacar la creación de las Intendencias, se procedió a someter aún más a la Iglesia americana; a este respecto, cabe destacar la aplicación del concepto francés de «Regalía», que los Borbones españoles pusieron en práctica mediante «El Regio Vicariato ${ }^{25}$.

${ }^{23}$ Ob. cit., pág. 409.

${ }^{24}$ Los conflictos entre la jerarquía diocesana y las órdenes religiosa fueron numerosas, solucionadas en gran parte por la intervención real, que tenía la base de su funcionamiento en la Bula Omnímoda, otorgada por Adriano en 1522.

${ }^{25}$ Los antecedentes del Regio Vicariato, datan del siglo XVI, defendidas primero por el clero regular, que preferían la dependencia real a la del clero secular; en este sentido destacan la defensa llevada a cabo por Alonso de la Veracruz y Juan de Solórzano. En el siguiente siglo destaca sobre todo la obra «Victima real legal» de Antonio Álvarez de Abreu, publicada en 1726, así como los escritos de José de Ayala. 
La razón de esta actitud del Estado respecto a la Iglesia, que se acentúa especialmente durante el reinado de Carlos III $^{26}$, «compete a mi real potestad intervenir en todo lo que compete al gobierno espiritual de las Indias, con tanta amplitud, que no sólo me está concedida por la Santa Sede sus veces en lo económico de las dependencias y cosas eclesiásticas, sino también en lo jurisdiccional y contencioso, reservándose sólo la potestad del orden, de que no son capaces los seculares ${ }^{27}$. Actitud, que no obstante, el monarca español quiere hacer compatible con la obligación de proteger a la Iglesia Católica en todo el ámbito del Reino, como se pone de manifiesto en la Instrucción I que da a la naciente Junta Suprema creada en $1778^{28}$,

"Como la primera de mis obligaciones, y de todos los sucesores en mi corona, sea la de proteger la religión católica en todos los dominios de esta vasta monarquía, me ha parecido empezar por este importante punto, para manifestaros mis deseos vehementes de que la Junta, en todas sus deliberaciones, tenga por principal objeto la honra y la gloria de Dios, la conservación y propagación de nuestra santa fe, y la enmienda y mejoría de las costumbres ${ }^{29}$.

No obstante, aunque se mantenga el principio de acatamiento a la Santa Sede en las materias espirituales, como pone de manifiesto la Instrucción $\mathrm{II}^{30}$,

«La protección de nuestra santa religión pide necesariamente la correspondencia filial de la España y sus soberanos con la Santa Sede, y así la Junta ha de contribuir con todas sus fuerzas á sostener, afirmar y perpetuar esta correspondencia, de manera que en las materias espirituales, por ningún caso ni accidente dejen de obedecerse y venerarse las resoluciones tomadas en forma canónica por el sumo Pontífice, como vicario que es de Jesucristo y primado de la Iglesia universal»,

lo que no obsta, para que se defiendan firmemente el Patronato y regalías de la Corona,

${ }^{26}$ Mediante la Real Cédula de 1765 se procedían a ampliar las competenciales al respecto.

27 TOMAdo DE Gloria, M.: «La consolidación del modelo constitucionalista republicano en Iberoamérica y sus consecuencias en el ámbito de la libertad religiosa: análisis macro-comparado de su evolución»; en Laicidad y libertades. Escritos Jurídicos, n. ${ }^{\circ} 200$, pág. 228.

${ }^{28}$ La Junta Suprema de Estado fue creada por Carlos III mediante Real Decreto de 8 de junio de 1787, configurándose como el origen del Consejo de Ministros de España, véase al respecto, Escudero, J. A.: «Los origenes del Consejo Ministros en España; 2 vols Madrid, 1979, Editora Nacional.

29 Instrucción I; en EsCUDERO, J. A., ob. cit., pág. 15, vol. II, que reproduce el texto manuscrito conservado en A.H.N..

${ }^{30}$ Instrucción II; en EsCUDERO, J. A., ob. cit., pág. 15, vol. II. 
«Pero, como además de los decretos pontificios, canónicamente expedidos para las materias espirituales, pueden mezclarse o expedirse otros que tengan relación con los decretos de patronatos y regalías, y con los asuntos de disciplina externa, en que, por las mismas decisiones eclesiásticas y por las leyes reales y costumbre inmemorial, me corresponden facultades que no se pueden ni deben abandonar, sin faltar á las más rigurosas obligaciones de conciencia y justicia, conviene que la Junta, cuando pudiere mezclarse alguna ofensa de aquellos derechos y regalías, me consulte los medios prudentes y vigorosos de sostenerlas, combinando el respeto debido a la Santa Sede con la defensa de la preeminencia y autoridad real $\aleph^{31}$.

La actuación de la Corona durante la segunda mitad del siglo, responde a dos aspectos fundamentales:

a) Incorporar a la administración eclesiástica como una rama más de la administración de la Corona y sujeta al vértice de la misma que es el Rey.

b) Gestionar los inmensos tesoros de la Iglesia americana, en un momento en que el Estado está sufriendo una profunda crisis económica como consecuencia de las interminables guerras derivadas de los Pactos de Familia, independencia de los Estados Unidos de Norteamérica, guerra con Francia, alianza contra Inglaterra.

La teoría del Vicario Regio, como indica John Fisher ${ }^{32}$ tenía su base en que la autoridad del Rey como Vicario General provenía no del Patronato Real concebido en los siglos XV y XVI, sino directamente de Dios ${ }^{33}$, ya que era un elemento inherente a la soberanía temporal incluida en el derecho divino de los reyes. De esta forma, como indica el citado autor,» por una combinación de Patronato Real y derechos divinos, la autoridad del Papa en América le había sido transmitida al Rey en todos los aspectos de la jurisdicción eclesiástica, salvo en el de la potestad de orden (las facultades sacramentales adquiridas por los clérigos al ordenarse), la cual, por ser de naturaleza sacerdotal, no podía ejercer ningún seglar». No obstante, es de resaltar que la Iglesia intentó en varias ocasiones suprimir algunas actuaciones del Estado, como el Pase Regio, en el que Pío V fracasaría, en un intento de delimitar el campo específicamente eclesiástico del

31 Instrucción III, en ESCUDERO, J. A., ob. cit., pág. 16., vol. II.

32 FISHER, J., «Las colonias americanas». En Historia de Iberoamérica. Tomo II. Ed. Cátedra, 1990, pág. 638.

33 Cabe destacar la actuación de algunos teólogos españoles en contra de la teoría del origen divino de los Reyes, entre ellos, el jesuita Francisco Suárez. 
ejercicio del poder terrenal ${ }^{34}$; por otra parte, no debe circunscribirse la intervención del Estado ${ }^{35}$ sólo a la época de los Borbones ${ }^{36}$, así como indica Sánchez Bella ${ }^{37}$ » Cuando se examina la actitud de los Reyes Católicos y de los Austrias frente a Roma, se suele producir una nota de asombro. Se advierte no solamente una sostenida tensión, sino también un lenguaje por parte de los Monarcas duro, áspero exigente. Y si de estas palabras se pasa a observar los hechos, el asombro aumenta al ver intervenir a los gobernantes en la vida de la Iglesia hasta límites insospechados ${ }^{38}$.

En el caso de la Iglesia en la América española-Las Indias occidentales, como entonces se denominaba al Nuevo Mundo-, no es el Papa, sino el monarca, quien gobierna, ordena y decide. De esta forma, la actuación de la Corona al respecto, responde a una actitud unilateral en la mayor parte de los casos, así como indica Alberto de la Hera, no se trata de normas concordadas, ya que el primer concordato de la historia de España es de $1753^{39}$, aunque

34 Ante la pretensión de la Corona de que eran atribuciones reales y no del papado, la Iglesia nunca reconoció este principio, aunque evitó una política confrontación con el Estado, mediante la práctica de la denominada teoría de la disimulación, antigua práctica canónica, por la que en muchos casos fingía ignorar el hecho; no obstante, debe resaltarse que ante la elaboración de la teoría real protagonizada por algunos juristas españoles, la Iglesia remitió sus libros al índice de libros prohibidos. Véase Bruno, C. El derecho público de la Iglesia en Indias Salamanca, 1967, pág. 153.

35 No obstante, ser este periodo, especialmente durante los reinados de Carlos III y Carlos IV, cuando la teoría de la «Regalía» alcanza su mayor auge.

${ }^{36}$ Lo que no obstaba, para que la Corona procediera a alcanzar determinados acuerdos con la Iglesia, véase a modo de ejemplo la Instrucción V de Carlos III a la Junta Suprema de Estado « Por esta razón se han reducido á concordatos con la Corte de Roma muchos puntos que, en rigor podrían haberse dirigido y resuelto de otro modo, con la autoridad sola de los reyes mis predecesores, y este recurso, y el de las concesiones ó indultos pontificios que yo he obtenido en mi tiempo para varias materias, ha sido muy provechoso, procurándose pedir y ejecutar los breves e indultos con la calidad de que no perjudiquen á los derechos y regalías de mi corona, y con preservación de ellos, siendo el fin de obtenerlos el de conservar la paz y armonía con los sumos pontífices»; en ESCUDERO, J. A., ob. cit., pág. 17., vol. II..

37 SÁNCHEZ Bella, I., «Iglesia y Estado español» en La edad Moderna (siglos XVI y XVII), Málaga, 1984.

38 Sobre la forma de entender las relaciones Vaticano-Corona de España, resulta esclarecedora la Instrucción VIII de Carlos III a la Junta Suprema de Estado, referentes a las cualidades que el sumo Pontífice debía tener "De aquí resulta el conato que se debe poner en que las elecciones de los papas se hagan en personas afectas á las coronas, y señaladamente á la de España, y en que sean de condición blanda y de mucha doctrina, vasta y sólida erudición, con lo cual sabrán moderar las exorbitantes pretensiones de la curia, y ceder á las instancias que se les hagan"; en ESCUDERO, J. A., ob. cit., pág. 17, vol. II.

39 De la Hera, A., «El gobierno espiritual de los dominios ultramarinos», en El gobierno de un mundo. Virreinatos y Audiencias en la América Hispánica Cuenca, Universidad de Castilla la Mancha, 2004, pág. 869. 
existiera un precedente bajo el reinado de Felipe V, que no llegó a entrar en vigor $^{40}$.

En la opinión que sostenemos, al margen de los conflictos existentes entre Iglesia y Estado, entre dos autoridades soberanas, el problema radica, en la propia concepción y fundación de la «nación española» ${ }^{41}$ y el rol otorgado a la religión católica en este proceso de formación, como aglutinante de esa nación, como elemento fundamental de la misma, de tal forma, que al mismo tiempo que la justifica, la conforma en unas determinadas directrices, aportándole una determinada misión en la historia, indisolublemente unida a la religión católica, así el concepto de " Monarquía Universal Católica», va íntimamente ligado al de Imperio español; evidentemente, la formación del Imperio español se adelanta mucho en el tiempo a la conformación del otro gran imperio histórico, el inglés y a otras entidades menores como el Imperio francés o el holandés, por lo que no es posible establecer un paralelismo perfecto, especialmente, en cuanto que el gran desarrollo de los otros imperios citados se producen cuando se ha realizado o se está produciendo el fenómeno de las revoluciones liberales o al menos del hundimiento del Antiguo Régimen, pero sí puede afirmarse que su fundación responde a criterios perfectamente diferenciados, destacando en el primer caso, el español, que junto al deseo de conseguir metales preciosos, se da la necesidad de exportar fuera de su territorio original, un modelo de sociedad y de organización similar al que tiene en la metrópoli, unido por el principio religioso y la lealtad al trono, lo que tiene consecuencias directas, tales como el mestizaje, la erección de grandes urbes, desarrollo de Cabildo abierto etc., mientras que en los otros casos indicados, su desarrollo fuera del territorio europeo responde a criterios económicos perfectamente definidos, como es la producción de materias primas y el establecimiento, no siempre, de colonias excedente de su población metropolitana, ya que en la mayor parte de los casos se crean factorías, que en el devenir del tiempo serán o no ciudades, reservadas sólo a su propia población inmigrante, pero en todo caso, no responde al criterio de crear una nueva sociedad, aunque al final, en algunos casos se creen respondiendo a criterios particulares (persecuciones religiosas, políticas etc.,), pero que no responden a un impulso estatal, como en el caso español o portugués, y cuyo desarrollo se cimienta exclusivamente sobre criterios económicos, pero no tiene como carácter prioritario la expansión religiosa, que se reserva sólo a los naturales de la me-

${ }^{40} \mathrm{El}$ anterior concordato data de 1737. Sobre ambos concordatos véase AYARRAGARAY, L. La Iglesia en América y la dominación española. Buenos Aires, 1920, pág. 167-171, en DE LA HERA A., ob. cit.

41 Véase Núñez Rivero, C. El Estado y la Constitución, Madrid, UNED, 1997. 
trópoli, en virtud, de que no tienen necesidad de atraer a la población autóctona trabajadora, por otra parte, generalmente importada de otros lugares (África y Extremo Oriente), ya que el establecimiento colonial responde en principio no a un deseo de permanencia, sino exclusivamente de expansión comercial.

La dependencia política y administrativa de la Iglesia respecto a la Corona no impidió que en los inicios del siglo XIX, en el momento del nacimiento de las nuevas repúblicas, acumulase una inmensa riqueza en los territorios americanos, de hecho, representaba el primer poder económico en las Indias.

El patrimonio de la Iglesia Católica en América se derivaba de los siguientes tipos de ingresos:

El diezmo ${ }^{42}$.

Las donaciones de los fieles.

La gestión de un enorme activo inmobiliario urbano ${ }^{43}$.

La propiedad de la tierra ${ }^{44}$.

Explotación de mano de obra indígena.

Aportaciones de la Corona al sostenimiento del clero y sus actividades.

La gestión de numerosas fundaciones y sociedades benéficas, que a su vez controlaban enormes patrimonios, normalmente inmobiliarios ${ }^{45}$.

42 Desde 1501, mediante la Bula Eximiae devotionis otorgada por Alejandro VI, el diezmo pasó de la Iglesia a la Corona « Os concedemos a Vosotros y a vuestros sucesores, que en dichas islas y provincias podáis percibir y llevar lícita y libremente los diezmos todos de sus vecinos, moradores y habitadores», aunque ello suponía que la Corona debía asumir todos los gastos derivados de las actividades eclesiásticas» (...) se haya de dar y asignar dote suficiente a las Iglesias, que en dichas Indias se hubieren de erigir, con la cual sus Prelados y Rectores se puedan sustentar congruamente». De esta forma, la aportación del Estado era mucho mayor que los diezmos recibidos; la concesión papal de los diezmos fue reiterada por Julio II en una nueva Bula Eximiae devotionis en 1510; no obstante, con el advenimiento de la Casa de Borbón, Felipe V, dispuso que la renta de los diezmos pudiera ser destinada a fines fijados por la Corona, que no tenían que ser forzosamente eclesiásticos.

43 Aunque la Corona prohibió a partir de 1576 que realizaran operaciones ordinarias de compraventa, la Iglesia contaba con el mayor patrimonio inmobiliario urbano del Nuevo Mundo.

${ }^{44}$ La Iglesia era el primer terrateniente en todo el continente, al menos en lo que se refiere a tierras productivas.

45 Este aspecto quedó altamente dañado mediante el Decreto de consolidación de 1804, por el que el Estado, en uso de sus prerrogativas confiscó estos fondos. La razón de la actuación de la Corona era la situación financiera debida entre otras cosas a las interminables guerras sostenidas en el exterior; posteriormente, el Decreto fue abolido en 1809 por la Junta Central durante la Guerra de la Independencia española. 


\section{LA IGLESIA EN LA CONFORMACIÓN DE LAS NUEVAS REPÚBLICAS}

En la actitud de la Iglesia ante la desintegración del Imperio español y la conformación de las Repúblicas hispanoamericanas, es preciso diferenciar los siguientes protagonistas:

\section{El Vaticano.}

La jerarquía eclesiástica americana.

El bajo clero regular.

La estrecha alianza mantenida entre la Corona española y el Papado durante toda la Edad Moderna, respondía no sólo a unos intereses concretos compartidos de poder temporal y espiritual, tanto en el Nuevo como en el Viejo Mundo, sino que implicaba además una concepción del mundo, que tenía su base en la misma raíz de organización de una comunidad política, en cuanto que tanto el Papa como el Emperador o Rey, en su caso, eran representantes (vicarios) de Dios en la tierra y por tanto todo cuestionamiento de este poder representaba quedar fuera de la Iglesia.

Por otra parte, la rebelión de las élites criollas contra la Monarquía Absoluta y a favor de la independencia se lleva a cabo desde el racionalismo y el utilitarismo encuadrados ideológicamente en las revoluciones burguesas, con especial incidencia de la independencia norteamericana y la revolución francesa, lo que implicaba forzosamente un cuestionamiento general de la actitud de la Iglesiainstitución, como ocurriera fundamentalmente con motivo de la conformación de los primeros Estados Constitucionales y los principios inspiradores de los mismos, que a la sazón ya habían sido duramente condenados por el Vaticano en reiteradas ocasiones, valga como ejemplo a este respecto las Cartas Encíclicas de Gregorio XVI "Mirari Vos» ${ }^{46}$, en la que centra su contenido en los "Errores modernos» y la "Singulari Nos» ${ }^{47}$, en la que igualmente incide en la condena a los principios del Estado Liberal. Así, refiriéndose a los males actuales que aquejaban a la sociedad de inicios del siglo XIX, centra su crítica en la destrucción del orden existente, tanto en lo espiritual, que ubicaba hasta el momento a la Iglesia Católica en la fuente y justificación del orden espiritual y temporal, no sujeta las leyes del Estado, como a los cambios acaecidos en el derecho y el "poder legítimo",

\footnotetext{
46 De 15 de agosto de 1832.

47 De 24 de junio de 1834.
} 
«Tristes, en verdad, y con muy apenado ánimo Nos dirigimos a vosotros, a quienes vemos llenos de angustia al considerar los peligros de los tiempos que corren para la religión que tanto amáis. Verdaderamente, pudiéramos decir que ésta es la hora del poder de las tinieblas para cribar, como trigo, a los hijos de elección. Sí; la tierra está en duelo y perece, inficionada por la corrupción de sus habitantes, porque han violado las leyes, han alterado el derecho, han roto la alianza eterna. Nos referimos, Venerables Hermanos, a las cosas que veis con vuestros mismos ojos y que todos lloramos con las mismas lágrimas. Es el triunfo de una malicia sin freno, de una ciencia sin pudor, de una disolución sin límite. Se desprecia la santidad de las cosas sagradas; y la majestad del divino culto, que es tan poderosa como necesaria, es censurada, profanada y escarnecida: De ahí que se corrompa la santa doctrina y que se diseminen con audacia errores de todo género. Ni las leyes sagradas, ni los derechos, ni las instituciones, ni las santas enseñanzas están a salvo de los ataques de las lenguas malvadas. Se combate tenazmente a la Sede de Pedro, en la que puso Cristo el fundamento de la Iglesia, y se quebrantan y se rompen por momentos los vínculos de la unidad $»^{48}$.

Así mismo, identifica la crisis de la Monarquía Absoluta con el cuestionamento de la autoridad de eclesiástica, de la que considera que es una consecuencia directa,

«Se impugna la autoridad divina de la Iglesia y, conculcados sus derechos, se la somete a razones terrenas, $y$, con suma injusticia, la hacen objeto del odio de los pueblos reduciéndola a torpe servidumbre. Se niega la obediencia debida a los Obispos, se les desconocen sus derechos. Universidades y escuelas resuenan con el clamoroso estruendo de nuevas opiniones, que no ya ocultamente y con subterfugios, sino con cruda y nefaria guerra impugnan abiertamente la fe católica. Corrompidos los corazones de los jóvenes por la doctrina y ejemplos de los maestros, crecieron sin medida el daño de la religión y la perversidad de costumbres. De aquí que roto el freno de la religión santísima, por la que solamente subsisten los reinos y se confirma el vigor de toda potestad, vemos avanzar progresivamente la ruina del orden público, la caída de los príncipes, y la destrucción de todo poder legítimo. Debemos buscar el origen de tantas calamidades en la conspiración de aquellas sociedades a las que, como a una inmensa sentina, ha venido a parar cuanto de sacrílego, subversivo y blasfemo habían acumulado la herejía y las más perversas sectas de todos los tiempos» ${ }^{49}$.

48 Encíclica MIRARI VOS, ob. cit.

49 En el párrafo de referencia perteneciente a la Mirari Vos se incluye claramente una crítica los clubes librepensadores y logias masónicas, crítica que se repetirá posteriormente en el citado documento n. ${ }^{\circ}$. 17: «(...) Nos preocupan y Nos llenan de dolor... ciertas asociaciones o reuniones, las cuales, confederándose con los sectarios de cualquier falsa religión o culto, simulando cierta piedad religiosa pero llenos, a la verdad, del deseo de novedades y de promover sediciones en todas 
Las encíclicas del Sumo Pontífice se centran igualmente en aspectos consustanciales con el primer Estado de Derecho, así se condena la libertad de conciencia,

«De esa cenagosa fuente del indiferentismo (religioso) mana aquella absurda y errónea sentencia o, mejor dicho, locura, que afirma y defiende a toda costa y para todos, la libertad de conciencia. Este pestilente error se abre paso, escudado en la inmoderada libertad de opiniones que, para ruina de la sociedad religiosa y de la civil, se extiende cada día más por todas partes, llegando la impudencia de algunos a asegurar que de ella se sigue gran provecho para la causa de la religión. ¡Y qué peor muerte para el alma que la libertad del error! decía San Agustín. Y ciertamente que, roto el freno que contiene a los hombres en los caminos de la verdad, e inclinándose precipitadamente al mal por su naturaleza corrompida, consideramos ya abierto aquel abismo del que, según vio San Juan, subía un humo que oscurecía el sol y arrojaba langostas que devastaban la tierra. De aquí la inconstancia en los ánimos, la corrupción de la juventud, el desprecio - por parte del pueblo- de las cosas santas y de las leyes e instituciones más respetables; en una palabra, la mayor y más mortífera peste para la sociedad, porque, aun la más antigua experiencia enseña cómo los Estados, que más florecieron por su riqueza, poder y gloria, sucumbieron por el solo mal de una inmoderada libertad de opiniones, libertad en la oratoria y ansia de novedades» ${ }^{50}$.

Libertad, que relaciona directamente con la destrucción del orden político,

«(...) Y por último acerca de la condenación de la omnímoda libertad de conciencia y de la terribilísima conspiración de las sociedades o de los secuaces de cualquiera de las falsas religiones, reunidos para la destrucción de la cosa sagrada y pública.... Rehuye, ciertamente nuestro ánimo, leer aquellas cosas con las que en esa misma obra el autor ${ }^{51}$ se esfuerza por romper cualquier vínculo de fidelidad y sujeción hacia los Príncipes, paseando por todas partes la tea de la rebelión con la que se producirá la destrucción del orden público, el desprecio de los magistrados, la destrucción de las leyes, arrancando por la fuerza todos los elementos de

\footnotetext{
partes, predican toda clase de libertades, promueven perturbaciones contra la Iglesia y el Estado; y tratan de destruir toda autoridad, por muy santa que sea».; otros escritos del siglo XIX del Vaticano de condena a la Masonería son: Benedicto XIV, Providas, 18 de mayo de 1751; Pío VII, Ecclesiam a Jesu Christo, 13 de septiembre, 1821; León XII, Quo Graviora, 13 de marzo, 1825; Pío VIII, Traditi Humaniti, Encíclica, 24 de mayo, 1829; Pío IX Qui Plúribus, Encíclica, 9 de noviembre, 1846; León XIII Humanum Genus, Encíclica, 20 de abril, 1884; León XIII, Inimica Vos, Encíclica 8 de diciembre, 1892; León XIII, Cusodi Di Quella FEDE, Encíclica 8 diciembre, 1892.

50 Encíclica Mirari Vos, ob. cit.

51 Se refiere a la obra «Paroles d'un croyant» de Lamennais.
} 
la potestad sacra y civil. De aquí con nueva e inicua invención presenta con portentosa calumnia la potestad de los Príncipes como contraria a la ley divina, y hasta como obra del pecado y poder de Satanás. Con las mismas calificaciones torpes como a los príncipes, difama a los que presiden las cosas sagradas, por medio del pacto de criminales maquinaciones contra los derechos de los pueblos con que sueña están unidos entre sí. No contento con un atrevimiento tan grande, propugna todavía la omnímoda libertad de opiniones, palabras y conciencias, y desea que todo suceda próspera y felizmente a los soldados de la causa que habrán de luchar, para libertarla de la tiranía, como él dice, y convoca con furioso entusiasmo a reuniones y sociedades en todo el universo, urgiéndoles con vehementes instancias a realizar tan nefastas determinaciones, de manera que también en este aspecto veamos desacatados nuestros avisos y prescripciones» ${ }^{52}$.

La concepción de la Monarquía Absoluta como sistema de gobierno que tiene su fuente en la voluntad divina, es defendida contra el nuevo sistema emergente en el Estado de Derecho,

«(...)Sabiendo Nos que se han divulgado, en escritos que corren por todas partes, ciertas doctrinas que niegan la fidelidad y sumisión debidas a los príncipes, que por doquier encienden la antorcha de la rebelión, se ha de trabajar para que los pueblos no se aparten, engañados, del camino del bien. Sepan todos que, como dice el Apóstol, toda potestad viene de Dios y todas las cosas son ordenadas por el mismo Dios. Así, pues, el que resiste a la potestad, resiste a la ordenación de Dios, y los que resisten se condenan a sí mismos. Por ello, tanto las leyes divinas como las humanas se levantan contra quienes se empeñan, con vergonzosas conspiraciones tan traidoras como sediciosas, en negar la fidelidad a los príncipes y aun en destronarles» ${ }^{53}$.

Proclama la obediencia debida, absoluta y ciega de los súbditos al poder real, sin que el mismo pueda ser cuestionado por los mismos, independendientemente de que los fines perseguidos sean o no lícitos, a tal efecto, sostiene en la base de su discurso una peculiar argumentación de carácter histórico, relacionando el concepto de «librepensamiento» con determinada «herejías» cristianas y con el luteranismo

«Por aquella razón, y por no mancharse con crimen tan grande, consta cómo los primitivos cristianos, aun en medio de las terribles persecuciones contra ellos levantadas, se distinguieron por su celo en obedecer a los emperadores y en luchar por la integridad del imperio, como lo probaron ya en el fiel y pronto

52 Singulari Nos; En, ob. cit.

53 Encíclica Mirari Vos, ob. cit. 
cumplimiento de todo cuanto se les mandaba (no oponiéndose a su fe de cristianos), ya en el derramar su sangre en las batallas peleando contra los enemigos del imperio. Los soldados cristianos, dice San Agustín, sirvieron fielmente a los emperadores infieles;.... Distinguían al Señor eterno del señor temporal; y, no obstante, por el primero obedecían al segundo. Así ciertamente lo entendía el glorioso mártir San Mauricio, invicto jefe de la legión Tebea, cuando, según refiere Euquerio, dijo a su emperador: Somos, oh emperador, soldados tuyos, pero también siervos que con libertad confesamos a Dios; vamos a morir y no nos rebelamos; en las manos tenemos nuestras armas y no resistimos porque preferimos morir mucho mejor que ser asesinos. Y esta fidelidad de los primeros cristianos hacia los príncipes brilla aún con mayor fulgor, cuando se piensa que, además de la razón, según ya hizo observar Tertuliano, no faltaban a los cristianos ni la fuerza del número ni el esfuerzo de la valentía, si hubiesen querido mostrarse como enemigos: Somos de ayer, y ocupamos ya todas vuestras casas, ciudades, islas, castros, municipios, asambleas, hasta los mismos campamentos, las tribus y las decurias, los palacios, el senado, el foro... ¿De qué guerra y de qué lucha no seríamos capaces, y dispuestos a ello aun con menores fuerzas, los que tan gozosamente morimos, a no ser porque según nuestra doctrina es más lícito morir que matar? Si tan gran masa de hombres nos retirásemos, abandonándoos, a algún rincón remoto del orbe, vuestro imperio se llenaría de vergüenza ante la pérdida de tantos y tan buenos ciudadanos, y os veríais castigados hasta con la destitución. No hay duda de que os espantaríais de vuestra propia soledad...; no encontraríais a quien mandar, tendríais más enemigos que ciudadanos; mas ahora, por lo contrario, debéis a la multitud de los cristianos el tener menos enemigos.

Estos hermosos ejemplos de inquebrantable sumisión a los príncipes, consecuencia de los santísimos preceptos de la religión cristiana, condenan la insolencia y gravedad de los que, agitados por torpe deseo de desenfrenada libertad, no se proponen otra cosa sino quebrar y aun aniquilar todos los derechos de los príncipes, mientras en realidad no tratan sino de esclavizar al pueblo con el mismo señuelo de la libertad. No otros eran los criminales delirios e intentos de los valdenses, beguardos, wiclefitas y otros hijos de Belial, que fueron plaga y deshonor del género humano, que, con tanta razón y tantas veces fueron anatematizados por la Sede Apostólica. Y todos esos malvados concentran todas sus fuerzas no por otra razón que para poder creerse triunfantes felicitándose con Lutero por considerarse libres de todo vínculo; y, para conseguirlo mejor y con mayor rapidez, se lanzan a las más criminales y audaces empresas» ${ }^{54}$.

Así mismo, la Iglesia no deja de manifestar la misión primordial de los Reyes de proteger la religión católica, anteponiendo su defensa incluso al ejercicio del

${ }^{54}$ Encíclica Mirari Vos, ob. cit. 
poder temporal, aspecto que en el caso americano, tiene especial relevancia, en virtud de la existencia del Patronazgo Regio, imperante en América durante tres siglos, aspecto que indisolublemente unía los fines del estado con los de la Iglesia Católica.

«(...) Que también los Príncipes, Nuestros muy amados hijos en Cristo, cooperen con su concurso y actividad para que se tornen realidad Nuestros deseos en pro de la Iglesia y del Estado. Piensen que se les ha dado la autoridad no sólo para el gobierno temporal, sino sobre todo para defender la Iglesia; y que todo cuanto por la Iglesia hagan, redundará en beneficio de su poder y de su tranquilidad; lleguen a persuadirse que han de estimar más la religión que su propio imperio, y que su mayor gloria será, digamos con San León, cuando a su propia corona la mano del Señor venga a añadirles la corona de la fe. Han sido constituidos como padres y tutores de los pueblos; y darán a éstos una paz y una tranquilidad tan verdadera y constante como rica en beneficios, si ponen especial cuidado en conservar la religión de aquel Señor, que tiene escrito en la orla de su vestido: Rey de los reyes y Señor de los que dominan " 55 .

Otros aspectos como la libertad de expresión o de imprenta proclamados en los textos constitucionales son igualmente combatidos en las encíclicas de referencia, reclamando para la Iglesia el derecho a ejercer la censura al respecto

«(...) Debemos también tratar en este lugar de la libertad de imprenta, nunca suficientemente condenada, si por tal se entiende el derecho de dar a la luz pública toda clase de escritos; libertad, por muchos deseada y promovida. Nos horrorizamos, Venerables Hermanos, al considerar qué monstruos de doctrina, o mejor dicho, qué sinnúmero de errores nos rodea, diseminándose por todas partes, en innumerables libros, folletos y artículos que, si son insignificantes por su extensión, no lo son ciertamente por la malicia que encierran; y de todos ellos sale la maldición que vemos con honda pena esparcirse sobre la tierra. Hay, sin embargo, joh dolor!, quienes llevan su osadía a tal grado que aseguran, con insistencia, que este aluvión de errores esparcido por todas partes está compensado por algún que otro libro, que en medio de tantos errores se publica para defender la causa de la religión. Es de todo punto ilícito, condenado además por todo derecho, hacer un mal cierto y mayor a sabiendas, porque haya esperanza de un pequeño bien que de aquel resulte. ¿Por ventura dirá alguno que se pueden y deben esparcir libremente activos venenos, venderlos públicamente y darlos a beber, porque alguna vez ocurre que el que los usa haya sido arrebatado a la muerte?

Enteramente distinta fue siempre la disciplina de la Iglesia en perseguir la publicación de los malos libros, ya desde el tiempo de los Apóstoles: ellos mismos

55 Encíclica Mirari Vos, ob. cit. 
quemaron públicamente un gran número de libros. Basta leer las leyes que sobre este punto dio el Concilio V de Letrán y la Constitución que fue publicada después por León X, de f. r., a fin de impedir que lo inventado para el aumento de la fe y propagación de las buenas artes, se emplee con una finalidad contraria, ocasionando daño a los fieles. A esto atendieron los Padres de Trento, que, para poner remedio a tanto mal, publicaron el salubérrimo decreto para hacer un Índice de todos aquellos libros, que, por su mala doctrina, deben ser prohibidos. Hay que luchar valientemente, dice Nuestro predecesor Clemente XIII, de p. m., hay que luchar con todas nuestras fuerzas, según lo exige asunto tan grave, para exterminar la mortífera plaga de tales libros; pues existirá materia para el error, mientras no perezcan en el fuego esos instrumentos de maldad. Colijan, por tanto, de la constante solicitud que mostró siempre esta Sede Apostólica en condenar los libros sospechosos y dañinos, arrancándolos de sus manos, cuán enteramente falsa, temeraria, injuriosa a la Santa Sede y fecunda en gravísimos males para el pueblo cristiano es la doctrina de quienes, no contentos con rechazar tal censura de libros como demasiado grave y onerosa, llegan al extremo de afirmar que se opone a los principios de la recta justicia, y niegan a la Iglesia el derecho de decretarla y ejercitarla» ${ }^{56}$.

La unión de la Iglesia y el Estado constituye uno de los más firmes baluartes a defender por el Papado,

«Las mayores desgracias vendrían sobre la religión y sobre las naciones, si se cumplieran los deseos de quienes pretenden la separación de la Iglesia y el Estado, y que se rompiera la concordia entre el sacerdocio y el poder civil. Consta, en efecto, que los partidarios de una libertad desenfrenada se estremecen ante la concordia, que fue siempre tan favorable y tan saludable así para la religión como para los pueblos ${ }^{57}$," siendo una de las manifestaciones más claras al respecto la defensa del control matrimonial por parte de la Iglesia «Aquella santa unión de los cristianos, llamada por el Apóstol sacramento grande en Cristo y en la Iglesia, reclama también toda nuestra solicitud, por parte de todos, para impedir que, por ideas poco exactas, se diga o se intente algo contra la santidad, o contra la indisolubilidad del vínculo conyugal. Esto mismo ya os lo recordó Nuestro predecesor Pío VIII, de s. m., con no poca insistencia, en sus Cartas. Pero aun continúan aumentando los ataques adversarios. Se debe, pues, enseñar a los pueblos que el matrimonio, una vez constituido legítimamente, no puede ya disolverse, y que los unidos por el matrimonio forman, por voluntad de Dios, una perpetua sociedad con vínculos tan estrechos que sólo la muerte los puede disolver. Tengan presente los fieles que el matrimonio es cosa sagrada, y que por ello está sujeto a

56 Encíclica Mirari Vos, ob. cit.

57 Encíclica Mirari Vos, ob. cit. 
la Iglesia; tengan ante sus ojos las leyes que sobre él ha dictado la Iglesia; obedézcanlas santa y escrupulosamente, pues de cumplirlas depende la eficacia, fuerza y justicia de la unión. No admitan en modo alguno lo que se oponga a los sagrados cánones o a los decretos de los Concilios y conozcan bien el mal resultado que necesariamente han de tener las uniones hechas contra la disciplina de la Iglesia, sin implorar la protección divina o por sola liviandad, cuando los esposos no piensan en el sacramento y en los misterios por él significados» ${ }^{58}$.

Con respecto a la independencia hispanoamericana, el Papado mantuvo desde el principio una condena de tal intento y una defensa de la soberanía regia; de esta forma, una vez el peligro napoleónico ha desaparecido de Europa y se ha producido el retorno absolutista de Fernando VII, Pío VII procede a la condena del movimiento libertador americano, ordenando a la Iglesia hispanoamericana denuncie tal intento de acabar con la soberanía real ${ }^{59}$. El apoyo vaticano a la causa realista se llevó a cabo durante todo el tiempo de la guerra de independencia $^{60}$, así cabe destacar que todavía en 1824 , a punto de producirse la debacle del sistema imperial español en América, se producirá una nueva encíclica ${ }^{61}$ dada por el Papa León XII, que defendía la causa realista contra la independencia republicana.

Los enfrentamientos entre el Vaticano y los independentistas hispanoamericanos no terminaron con la creación de las repúblicas soberanas ${ }^{62}$, de hecho, hasta el pontificado de Gregorio XVI (1831-1846) no se normalizaron plenamente las relaciones. Las razones de las desavenencias entre la Iglesia y los nuevos Estados no se circunscribían únicamente a aspectos de carácter ideológico y de concepción del poder político; la Iglesia, aunque muy mermada en su patrimonio americano como consecuencia del decreto de consolidación de 1804 y de la propia guerra de la independencia, donde numerosos inmuebles y

58 Encíclica Mirari Vos, ob. cit.

59 Encíclica Etsi longissimo, de 30 de enero de 1816.

${ }^{60}$ Incluso durante el Trienio liberal en España (1820-1823), que se llegaron a romper las relaciones entre España y el Vaticano, mediante la expulsión del Nuncio de Su santidad en España en enero de 1823, el Vaticano no dejó de apoyar la causa real, pero sí intentó desarrollar una política más desligada de la Corona española, aunque no de los principios del absolutismo; a este efecto, envió una delegación al Nuevo Mundo (1823), entre cuyos miembros figuraba el futuro Papa Pío XI; no obstante el triunfo de nuevo en España del Absolutismo ese mismo año apoyado por la Santa Alianza hizo que se volviera a la vieja alianza Corona Española-Papado.

${ }^{61}$ Encíclica Etsi iam diu, de 24 de septiembre de 1824.

${ }^{62}$ Véase al respecto, NúNEZZ Rivero, C.; NúNEZZ MarTíneZ, M.; «Iglesia y religión en los primeros textos constitucionales hispanoamericanos: Virreinatos de Nueva Granada y Perú». Revista Nueva época Universidad Libre Bogotá, 2007, n. ${ }^{\circ}$ 28, págs. 39-71. 
haciendas habían quedado destruidos o abandonados, seguía siendo el mayor poder económico en el continente y las jóvenes repúblicas aspiraban a suceder a la Corona en las prerrogativas que ésta tenía sobre el control de entidades benéficas y determinados bienes, así como sobre el nombramiento de los altos cargos eclesiásticos en virtud del Regio Patronato, que pretendían heredar como derecho traspasado por la Corona mediante el acceso a la independencia. Por su parte, el Vaticano, al haber reasumido la potestad de hacer las designaciones, como no reconocía a los nuevos Estados, no podía proceder a realizar nuevos nombramientos ${ }^{63}$. Por otra parte, cabe destacar el apoyo con que todavía contaba en el Vaticano el Monarca español Fernando VII, que se oponía tenazmente a que se nombraran obispos en América, si no era por su persona, ya que ello significaría el reconocimiento de la independencia de las nuevas naciones americanas.

Como consecuencia de estos enfrentamientos, sea por defunción o abandono, numerosas sedes arzobispales y obispados quedaron vacantes. Así como indica Leslie Bethell ${ }^{64}$ «En 1825, por ejemplo, el arzobispo de Arequipa, José Sebastián Goyeneche y Barrera, era el único obispo legítimo en toda el área que hoy ocupan Ecuador, Perú, Bolivia, Chile y Argentina. La muerte del arzobispo de Guatemala y del obispo de Puebla en 1829 dejó a México y a Centroamérica sin un solo obispo. Estos son algunos de los obispados que permanecieron sin ocupar durante un largo periodo: México, 1824-1839; Michoacán, 18101831;Oaxaca, 1828-1841; Guatemala, 1830-1844; Nicaragua, 1825-1849; Caracas, 1817-1827; Bogotá,1818-1827; Cuenca, 1814-1847; Lima, 1822-1834; Trujillo, 1821-1836; Concepción, 1817-1832; La Plata, 1816-1834; Santa Cruz, 1813-1835; Asunción, 1820-1845; Buenos Aires, 1813-1833; Córdoba, 1816-1857.

Respecto al alto clero de la Iglesia americana, debe destacarse, que al igual que el Vaticano, apoyó sin reservas la causa realista en la figura de Fernando VII contra los movimientos independentistas, con más fervor incluso que el alto cle-

${ }^{63}$ A ello, se sumaba el problema de los nombramientos eclesiásticos llevados a cabo por la Junta de Regencia durante la ocupación de España por las tropas napoleónicas, cuya validez se impugnaba, en virtud de que dicho cuerpo carecía de facultades para formularlas, toda vez que éstas sólo correspondían a los reyes con base en el patronato de que gozaban. Como prueba de la fuente de conflicto que ello significaba, cabe citar el caso del Obispo de Michoacán en Nueva España, Manuel Abad y Queipo, quien excomulgó a Hidalgo y Morelos. La mayor parte de estos nombramientos no fueron ratificados ni por Fernando VII a su vuelta, ni por el Vaticano; CUEVAS, M., Historia de la Iglesia en México, Tomo V, pág. 65.

${ }^{64}$ BeTHeLl, L., «La Iglesia y la independencia latinoamericana». En Historia de América Latina, vol. V Barcelona, Ed. Crítica, 1991, pág. 206. 
ro de la España peninsular, parte del cuál acudió a la convocatoria de Bayona hecha por el Emperador Napoleón Bonaparte.

La jerarquía eclesiástica americana era de extracción mayoritariamente peninsular ${ }^{65}$ y consecuencia del Regio Patronato y, como se indicó anteriormente, incardinada en la organización administrativa española, por lo que su identificación con los principios de la Corona era completa ${ }^{66}$. De hecho, en muchos casos el paso por un Arzobispado americano suponía un escalón más en la carrera eclesiástica para obtener una sede importante en España.

Es por ello, que son contadas las adhesiones directas del alto clero a la causa independentista ${ }^{67}$, aunque debe destacarse que el movimiento independentista intentó siempre atraer a su causa a la jerarquía eclesiástica.

Los desacuerdos entre los caudillos independentistas y el alto clero se trasladarían posteriormente a los nuevos Estados y aunque se proclamó en ellos la Religión Católica como la religión oficial del Estado, lo que se llevó a cabo en contra de los sectores más radicales de las elites criollas, influenciados por la ideología liberal, el status de la Iglesia, aunque todavía altamente influyente, en cuanto era un poder económico, controlaba la educación y ejercía una enorme influencia no sólo sobre los sectores más conservadores y ricos de la sociedad, sino también en los sectores más populares, incluidos los indígenas, se verá mermado por los textos constitucionales, que al menos defenderán si no el laicismo, sí una suerte de tolerancia religiosa, al mismo tiempo que abolían para siempre el Tribunal del Santo Oficio. Ello derivará en conflictos casi constantes a lo largo del siglo XIX entre la jerarquía católica y las nuevas repúblicas, que a veces contribuirán decisivamente al desarrollo de numerosos enfrentamientos, e incluso guerras civiles.

El bajo clero fue el único estamento de la Iglesia en el que se produjeron ciertos apoyos a la causa independentista y constitucional, lo que puede considerarse consecuencia del mayor número de criollos y mestizos existentes en el mismo, que era incluso predominante en el clero secular, aunque al igual que ocurría en la Administración estatal tenía muy difícil acceso a la jerarquía eclesiástica, en virtud del monopolio mantenido por el sector proveniente de la pe-

65 Valga como ejemplo, que en Nueva España, el nombramiento del primer obispo criollo se produjo en la sede de Puebla en 1808.

${ }^{66}$ No obstante, cuando existían dudas de la lealtad a la Corona de algún alto cargo de la jerarquía eclesiástica americana, éste será cesado y devuelto a la Península o separado de su diócesis, caso de Narciso Coll y Prat, de Caracas, y de José Pérez y Armendáriz, de Cuzco.

${ }^{67}$ Antonio de San Miguel en Michoacán (México) y José de Cuero y Caicedo en Quito. (Ecuador). 
nínsula; por otra parte, existía un grave malestar por las diferencias de rentas y consideración social existentes entre el bajo clero y la jerarquía eclesiástica, que se había visto agravado por el decreto de consolidación de 1804, que en muchos casos había afectado a las únicas fuentes de ingresos con que contaba este amplio sector clerical, como las capellanías y pequeñas rentas; así mismo, la desaparición de gran parte del fuero eclesiástico, como consecuencia de las medidas borbónicas, había significado la pérdida de la inmunidad ante la jurisdicción civil. De esta forma, como se plantea John Fisher ${ }^{68}$ "¿Supuso realmente la subordinación de la Iglesia una ventaja para la Corona? Esta cuestión es tan importante, como difícil de contestar. A largo plazo, la evidente merma de independencia sufrida por la Iglesia, tanto desde el punto de vista de su autoridad en general como el de su fuero, sirvió en realidad para que muchos curas decidieran apoyar la rebelión contra el gobierno español e impulsaran al pueblo a luchar por la independencia valiéndose del argumento de que no sólo la Iglesia, sino también la religión habían estado en peligro a causa del regalismo de los Borbones». En todo caso, si como consecuencia de las guerras de independencia, la Iglesia como institución salió debilitada, en virtud de las pérdidas económicas, ya comenzadas anteriormente en 1804, en el factor humano la debacle fue muy superior, afectando al alto clero en las numerosas sedes que quedaron vacantes, como se indicó en epígrafe anterior y en el importante retorno de algunos de sus miembros a España y especialmente en el bajo clero, así como indica Leslie Bethell ${ }^{69}$ "No se sabe con certeza hasta qué punto quedaron desintegradas las estructuras eclesiásticas situadas por debajo del nivel del episcopado. Algunos clérigos murieron y otros regresaron a España. En muchos lugares, la disciplina se había resquebrajado a causa del faccionalismo de las guerras y por la pérdida del contacto con Roma. Parece ser que la vocación religiosa, se convirtió en menos atractiva en el período posrevolucionario; con ello la Iglesia quizás perdió el 50 por ciento del clero secular, e incluso más del regular. En México, por ejemplo, el número de seculares disminuyó de 4.229 en 1810 a 2.282 en 1834, y el de regulares de 3.112 en 1810 a 1726 en 1831 . En la provincia franciscana de Lima, el porcentaje anual de profesiones descendió del 6,9 de las tres décadas de 1771-1800 al 5,3 (1801-1810), al 2,3 (1811-1820) y a ninguna entre 1821 y 1837. Al cabo de un año de haberse proclamado la República en Bolivia, 25 de los 41 conventos del país habían cerrado sus puertas, aunque en este caso la hostil legislación de Bolívar y Sucre, indudablemente jugó un papel importante».

\footnotetext{
${ }^{68}$ FiSHER, J.; ob. cit., pág. 641.

${ }^{69}$ BeTHell, L., ob. cit., pág. 206.
} 
Aunque no es posible cuantificar el porcentaje del clero secular que apoyó el movimiento independentista hispanoamericano, sí puede afirmarse que en el bajo clero fue muy superior al habido en el alto clero, así como en el referente a las órdenes religiosas, muchos de cuyos miembros eran nacidos en la península; no obstante, puede destacarse que algunos sacerdotes jugaron un papel de primer orden en el movimiento revolucionario, caso de los curas Hidalgo y Morelos en México, que supieron unir las creencias religiosas populares al movimiento insurreccional ${ }^{70}{ }^{71}$, y dónde cerca de cien curas fueron ejecutados, así como otros tantos excomulgados ${ }^{72}$, en Quito, tres sacerdotes proclamaron la independencia en 1809, y en 1814 un general realista confeccionó una lista de 100 curas que se encontraban en el bando insurgente. En Santa Fe de Bogotá, tres sacerdotes fueron miembros de la Junta de 1810 y 9 participaron en el Congreso de $1811^{73}$. Dieciséis religiosos firmaron la declaración de independencia del Río

${ }^{70}$ Proclamaron a la Virgen de Guadalupe patrona de la independencia hispanoamericana. Sobre este hecho, a modo de anécdota, pero representativo del pensamiento de un sector del liberalismo hispanoamericano, cabe resaltar el comentario de Simón Bolívar al respecto «Felizmente los directores de la independencia de México se han aprovechado del fanatismo con el mejor acierto, proclamando a la famosa Virgen de Guadalupe por Reina de los patriotas; invocándola en todos los casos arduos y llevándola en sus bandera. Con esto, el entusiasmo político ha formado una mezcla con la religión, que ha producido un fervor vehemente por la sagrada causa de la libertad»; Simón Bolívar «Contestación de un americano meridional a un caballero de esta isla» Kingston, 6 de septiembre de 1815. En «Discursos, proclamas y epistolario político», Madrid, 1981.

${ }_{71}$ Aunque también este aspecto de las creencias populares fue utilizado por las fuerzas realistas, valga destacar el desarrollo que alcanza durante este periodo el culto a la Virgen de los Remedios y a la que el Virrey D. Francisco Javier de Venegas, entregó su bastón de mando, proclamándola "generalísima y capitana general del ejército", bordando así mismo su imagen en numerosas banderas.

${ }^{72}$ Cabe destacar entre los precursores de la Independencia al mercedario fray Melchor de Talamantes, peruano de origen, que contribuyó decisivamente a la convocatoria del Congreso $\mathrm{Na}$ cional del Reino de Nueva España, muerto en 1809 en la fortaleza de San Juan de Ulúa, así como al fraile Servando Teresa de Mier, al carmelita Gregorio Melero,.al franciscano Bernardo Conde, el mercedario Pedro Bustamante, a los sacerdotes Mariano Balleza, Francisco Olmedo, Nicolás Nava, José María Salcedo, Antonio Ruíz, Antonio Belén e Ignacio Hidalgo.

73 Por ello, aunque de proporciones claramente exageradas, pero como consecuencia del poder que tenía la Iglesia Católica como institución sólidamente organizada en las nuevas naciones, al menos en Colombia, son ejemplo las manifestaciones llevadas a cabo por Presidente de la Junta de Cundinamarca, Jorge Tadeo Lozanoes, en su discurso de apertura de 1813, «Sacerdotes fueron los que dirigían el impulso del pueblo en todas sus aspiraciones, no sólo en la capital, sino en Socorro, Pamplona y el Reino entero; en una palabra, hasta nuestra más remota posteridad recordará con gratitud que la revolución que nos emancipó fue una revolución clerical». En GROOT, J. M.; "Historia eclesiástica y civil de Nueva Granada». Bogotá, 1953, pág. 185. 
de la Plata y trece de Guatemala y 26 de los 57 diputados en el Congreso de Perú eran eclesiásticos ${ }^{74}$.

No obstante lo indicado, y aunque no tenga una relación directa con los hechos comentados anteriormente, debe destacarse la labor ejercida por los centros educativos jesuitas, como el Colegio Máximo de San Pedro y San Pablo en la ciudad de México, el Colegio de San Ildefonso en la misma ciudad, el del Espíritu Santo de Puebla, así como en otros lugares de Nueva España, que tanto contribuyeron a crear una identidad nacional mexicana entre las elites criollas, diferenciada de la española peninsular ${ }^{75}$. Valga como ejemplo de esta actuación el comentario de Gerard Decorme «Trascendental cual ningún otro acontecimiento para la ilustración de los criollos fue el establecimiento de los estudios de los jesuitas en México. Aunque existía la Universidad, no se halla más que una clase de gramática que prepara a ella y aún muy pocas escuelas de primeras letras. Así que la juventud, a pesar de sus buenas disposiciones, crecía sin formación literaria, con grave perjuicio de su educación moral y religiosa. Tanto y bien llenaron los jesuitas este vacío, que puede decirse que durante la época colonial ejercitaron casi sin competidores y gratuitamente este ministerio de la pública enseñanza ${ }^{76}$, y como indica Palomera ${ }^{77}$ "La formación intelectual y el desarrollo de las facultades humanas que recibían los alumnos en los cursos de filosofía impartidos en los colegios jesuitas de la Nueva España eran de gran importancia (...) Había en la Nueva España una formación filosófica que constituiría el arranque de su grandeza científica, el nervio de sus instituciones políticas, el respaldo de su unidad de fe y la base de su tranquilidad pública y prosperidad económica.»

Title

The religion in the nacional spanish american formation and in the origins of its Constitucional State

${ }^{74}$ Véase Bethell, L., ob. cit., págs. 204-208.

75 Aunque no existe un trabajo monográfico al respecto, Véase sobre el caso mexicano, RICARD, R. «La conquista espiritual de México. México, 1999; DeCORME, G. (SJ), «La obra de los jesuitas mexicanos durante la época colonial (1572-1767)»; PALOMERA, E. J., La obra educativa de los jesuitas en Puebla.

76 Decorme, G. (SJ), ob. cit.

77 Palomera, E. J., ob. cit., pág. 130. 


\section{Summary}

1. RECORDS: THE RELIGION IN THE CONFORMATION OF THE SPANISH EMPIRE. 2. THE RELIGION IN THE AMERICAN STATE FORMATION. 3. THE RELIGION IN THE CONFORMATION OF THE NEWS REPUBLICS

\section{Resumen}

El artículo resalta la importancia de la Iglesia Católica en la conformación del Imperio español, como consecuencia de la importancia de dicha Institución en la formación y legitimación tanto de la Monarquía Autoritaria de los Reyes Católicos como en el posterior periodo de Monarquía Absoluta, de tal forma que puede considerarse a la religión como el elemento unificador del poder político y aglutinante de la Nación española primero y posteriormente del Imperio español.

Las razones de la Corona para la expansión de la religión a las Indias es consecuencia en principio de la doctrina de la teocracia desarrollada en el medioevo a favor de la universal soberanía papal, que legitimaba la adquisición de nuevos territorios para los Monarcas cristianos, en virtud de que ello significara la incorporación al seno de la Iglesia de estos pueblos.

La evangelización americana se produce mediante la tutela del Estado y no teniendo como centro de impulsión al Vaticano, poniéndose de manifiesto la incardinación de la acción religiosa en el contexto de la política imperial, de tal forma que el papado debió conceder una serie de privilegios al Rey conocidos como el Derecho de Patronato Americano, control estatal que se consolidará mediante el Pase Regio obtenido por el Emperador Carlos V en 1538, y que alcanzará el máximo control estatal durante el siglo XVIII con la aplicación del concepto francés de regalía.

En virtud de la estrecha alianza indicada entre Iglesia y Monarquía Absoluta el proceso independentista criollo chocaría frontalmente con las jerarquías eclesiásticas, de tal forma que son numerosos los escritos papales condenatorios de la independencia americana.

\footnotetext{
Abstract

The article stresses the importance of the Catholic church in the formation of the Spanish Empire, as a result of the significance of that institution in the formation and legitimation of the authoritarian Monarchy of the Catholic Kings as well the following period of the Absolute Monarchy, in such a way that religion can be considered as the unifying element of the political power and agglutinative factor of the Spanish nation first, and of the Spanish Empire later.
} 
The reasons for the Crown to expand the religion across the Indies are based, in principle, in the doctrine of theocracy developed in the Middle Age to support the universal sovereignty of the Pope, which legitimated the acquisition of new territories in favour of the Christian monarchs, as it would mean the inclusion of those peoples in the bosom of the Church.

The American evangelization took place thanks to the support of the State and without having the Vatican as focus of impulsion, showing, this way, the placing of the religious action in the context of the imperial policy, in such a way that the Papacy was forced to grant different privileges (know as the American Patronage Right)to the King. This prerogative of the state will be consolidated through the "Pase Regio" acquired by the Emperor Charles V in 1538 and will reach the highest point of state control during the XVIII century through the implementation of the "royalties» French concept.

Under the close alliance between Church and Absolute Monarchy the Creole pro-independent process will clash against the ecclesiastic hierarchies as witnesses the large number of papal documents condemning the American independence.

Palabras clave

Hispanoamérica, Iglesia, Estado, Constitución

Key words

Latin America, Church, State, Constitution 